\title{
Italian Restaurants in Danish Consumers' Perceptions: A Multi-Cue Analysis in a Product Country Image Perspective
}

\author{
Elisa Martinelli ${ }^{1} \&$ Francesca De Canio $^{1}$ \\ ${ }^{1}$ Department of Economics "Marco Biagi”, University of Modena and Reggio Emilia, Modena, Italy \\ Correspondence: Elisa Martinelli, Department of Economics "Marco Biagi”, University of Modena and Reggio \\ Emilia, Modena, Italy, Viale Berengario, 51-41121 Modena, Italy. E-mail: elisa.martinelli@unimore.it
}

Received: October 3, 2019

doi:10.5539/ijbm.v14n12p138
Accepted: October 30, $2019 \quad$ Online Published: November 10, 2019

URL: https://doi.org/10.5539/ijbm.v14n12p138

\begin{abstract}
Studies on the country image topic in the services context are rare in comparison with the number of papers investigating the effect that the information on the country of origin exerts on consumer buying behavior when tangible products are concerned. To this regard, the current paper would contribute to the literature on the country-of-origin effect and consumer behavior, exploring the role played by Product Country Image (PCI) in shaping customers attitude when a service offer is concerned - namely: dining services. Specifically, this study tests a conceptual model developed in a multi-cue perspective, that is: evaluating not only the effect of the information on the origin of the service offer investigated, but also assessing consumers' perceptions related to other service offer cues, such as service quality and perceived value, in this case. A specific national cuisine in the full-service restaurant setting is explored: the Italian one.

From the methodological viewpoint, a survey was conducted among Danish customers of Italian restaurants in Copenhagen. The research method employed consisted in a structured questionnaire. Then, Structural Equation Modelling (SEM) was applied to the data collected. Results evidence that product country image influences the formation of a positive attitude towards ethnic restaurants even when a multi-cue approach is employed. Scientific and managerial implications are discussed.
\end{abstract}

Keywords: Italian restaurants, danish consumers, product country image, structural equation modelling

\section{Introduction}

The literature on the country-of-origin (COO) effect has a long tradition and may count on a very high number of studies. The topic caught the research interests of hundreds of scholars from the 60ies onwards (e.g.: Schooler, 1965; Han, 1989; Roth \& Romeo, 1992; Martin \& Eroglu, 1993; Papadopoulos \& Heslop, 2003; Usunier, 2006; Zeugner-Roth \& Diamantopoulos, 2009) and is continuing to receive great attention by academics (e.g.: Zeugner-Roth, Žabkar \& Diamantopoulos, 2015; Fischer \& Zeugner-Roth, 2017; Motsi \& Park, 2019). Nevertheless, this is a very complex and fragmented research area and further studies are needed in order to increase the academic knowledge on the phenomenon (Verlegh \& Steenkamp, 1999). This also because the relevance and practical usefulness of COO theory has been questioned (Samiee, 2010).

Studying the rich literature on the COO effect, a gap is evident: the related papers are mainly aimed at analysing consumers' perceptions and behaviours in relation to tangible products, while studies investigating the effect of country image (CI) in the services sector are rare (Ahmed, Johnson, Ling, Fang \& Hui 2002; Berentzen, Backhaus, Michaelis, Blut, \& Ahlert, 2008). In order to contribute in filling this gap, this study investigates the effect of Product Country Image (PCI) on consumers attitude when a service offer is concerned. Specifically, a conceptual model is tested in the full-service restaurant setting, applying a multi-cue perspective, viz.: evaluating not only the effect of the information on the origin of the service offer investigated (PCI), but also assessing consumers' perceptions related to other service offer cues, such as service quality and perceived value, and controlling for demographic variables (gender and age). As service quality in the restaurant literature is conceptualised as a multi-dimensional construct, in this study we assessed its three main components: Food, Ambience and Staff (Susskind \& Chan, 2000).

The full-service restaurant channel is an interesting services sector to investigate. It accounts for $52 \%$ of the global catering market and is experiencing a steady growth (Deloitte, 2017). Within this encouraging sector 
development, ethnic restaurants represent an important component and are expected to progress as consumers are increasingly interested in ethnic cuisines. The PCI investigated is that of the Italian cuisine, one of the most appreciated worldwide (Hjalager \& Corigliano, 2000), the second at the global level after the Chinese one, with around $13 \%$ of the market share in terms of number of transactions, with a business volume of 209 billion euros (Deloitte, 2017).

The study took place in Copenhagen and Danish consumers' perceptions were collected administering a structured questionnaire to a sample of customers of a number of Italian restaurants. Then, Structural Equation Modelling (SEM) was applied to the data collected.

The paper is structured as follows. After a brief description of the underpinnings of the COO effect in extant literature and its role in relation to services and ethnic restaurants in particular, the work would present the theoretical framework and the hypotheses supporting the proposed model. Then, the research methodology would be described, highlighting the measurements employed and the confirmatory factor analysis performed. The results are then depicted and discussed, evidencing the possible limitations and further research directions of this study.

\section{Country of Origin, Services and Ethnic Restaurants}

According to the cue utilization theory, consumers make their inferences about the quality of a product based on a number of cues such as price, brand, packaging, etc. Traditionally, country-of-origin is conceptualized as one of these cues, specifically an extrinsic and cognitive cue, consisting in an informational stimulus regarding the origin of a merchandise that is used by consumers to assume beliefs regarding product attributes (Bilkey \& Nes, 1982) and form their preferences.

The COO literature states that consumers are impacted by the origin of a product depending on the kind of product category they are facing with (Ahmed \& d'Astous, 1995). However, the literature on the COO effect when a services offer is contemplated is scarce and contradictory: some authors consider the effect as similar to what is happening when tangible products are concerned (Javalgi, Cutler \& Winans, 2001), while other academics suggest that the special features possessed by services in comparison with tangible products - such as intangibility, perishability, heterogeneity, and inseparability (Zeithaml, Parasuraman \& Berry 1985) - are enhancing the effect that COO exerts on consumers (Pecotich, Pressley \& Roth, 1996). Moreover, some papers state that the $\mathrm{COO}$ effect may differ between service categories (e.g., Michaelis, Woisetschläger, Backhaus \& Ahlert, 2008) and as studies on the way in which the information on the country-of-origin of a service offer affects consumer buying behaviour are limited mainly to banking, airlines and insurance (Pecotich et al., 1996; Lin \& Chen, 2006; Berentzen et al., 2008), a specific attention to dining services might contribute to shed light on the topic.

To widen our understanding on the role played by PCI when an ethnic restaurant is concerned, a theoretical model is proposed, with the related hypotheses, as described in the following paragraph.

\section{Theoretical Framework and Hypotheses}

The perspective used in the current study lays in attitudinal research in consumer behavior and international marketing. Scholars agree in considering consumer attitude as a key predictor of customer behaviors (Fishbein \& Ajzen, 1975). In fact, customers' previous experiences with a product or service result in the formation of an attitude toward the supplier that is consistently associated with consumers' intentions to repurchase and recommend. This has been found true also when food is concerned: a positive attitude towards ethnic food was found to be a predictor of actual food purchases (Choo, Chung \& Pysarchik, 2004).

In this context, this paper proposes a model in which a multi-cue analysis is performed, considering the influence exerted by PCI on consumers attitude together with the main cues that the literature on consumer behaviour in restaurant settings found relevant - that is: perceived value and perceived service quality - and controlling for gender and age. Perceived service quality is considered as composed by three main restaurant attributes: food, staff and atmosphere (see Fig. 1).

Perceived value is defined as the result of the comparison between perceived benefits and sacrifices by the customer (Zeithaml, 1988; McDougall \& Levesque, 2000). It is a subjective factor as it is involving an evaluative judgment. Perceived value was found to predict consumer attitude (Swait \& Sweeney, 2000; Im, Bhat \& Lee, 2015), also in the dining services when an ethnic cuisine is concerned (Ha \& Jang, 2010a). The first hypothesis posits as follows:

H1: Perceived Value of Italian restaurants (PV) positively impacts on Attitude towards eating in an Italian restaurant (ATT). 
Service quality results as being the most researched subject in services marketing (Fisk, Brown \& Bitner, 1993). Several studies on consumer behavior in restaurants suggest that service quality significantly influences consumers' decisions and perceptions regarding restaurants (Clemes, Gan \& Sriwongrat, 2013). Customer perceived service quality can be defined as a global judgment relating to the superiority of service in relation to competing offerings (Parasuraman, Zeithaml \& Berry, 1988). Perceived quality in the dining setting was found to influence attitude towards the restaurant (Ha \& Jang, 2010b; Han \& Hyun, 2017). A similar effect might be expected when an ethnic full-service restaurant is concerned. The second hypothesis underlying the theoretical study is consistently formulated, as follows:

H2: Perceived Quality of Italian Restaurants (PQ) positively impacts on Attitude towards eating in an Italian restaurant (ATT).

Within the $\mathrm{COO}$ literature, a progressive interest has raised towards country image (CI), defined as "the total of all descriptive, inferential and informational beliefs one has about a particular country" (Martin \& Eroglu, 1993, p. 193). A product country image (PCI) can be defined as the total of all descriptive, inferential and informational beliefs one has about a specific product from a particular country. When consumers possess a positive image of a specific product category originated in a certain country, their attitude can be affected in the same direction. The third hypothesis characterizing the study is consistently formulated as follows:

H3: Product Country Image (PCI) positively impacts on Attitude towards eating in an Italian restaurant (ATT).

Previous research has suggested that food, atmospherics, and employees are three major components of the restaurant experience (Susskind \& Chan, 2000).

Food is the most essential part of the overall restaurant experience (Sulek \& Hensley, 2004). Moreover, Food is considered as one of the most important factors contributing to customers' perceived authenticity of ethnic restaurants (Aishah et al., 2010; Tsai \& Lu, 2012; Kim \& Jang, 2016).

For decades, scholars have expressed interest in the role of the physical environment, or "atmospherics" on customer perceptions of quality and subsequent responses. In fact, consumers may use the stimuli coming from the ambiance as tangible cues to assess the quality of the services provided, particularly when an ethnic restaurant is concerned (Han \& Ryu, 2009; Mohsin \& Lockyer, 2010; Tsai \& Lu, 2012; Amin, Yahya, Ismayatim, Nasharuddin, \& Kassim, 2013).

The restaurant staff is key in generating a positive perception of the quality of the service offered. It refers to the customer's perception about employee service during service delivery, characterised by employees' attitude, behaviour and expertise (Amin et al., 2013).

Accordingly, the fourth hypothesis is declined into three complementary hypotheses investigating the effect of these service attributes on the overall perceived quality of Italian restaurants, as follows:

H4a: The Staff of the restaurant (STAFF) positively impacts on Perceived Quality of Italian Restaurants (PQ).

H4b: The Atmosphere of the restaurant (ATMO) positively impacts on Perceived Quality of Italian Restaurants (PQ).

H4c: The Food of the restaurant (FOOD) positively impacts on Perceived Quality of Italian Restaurants (PQ). 


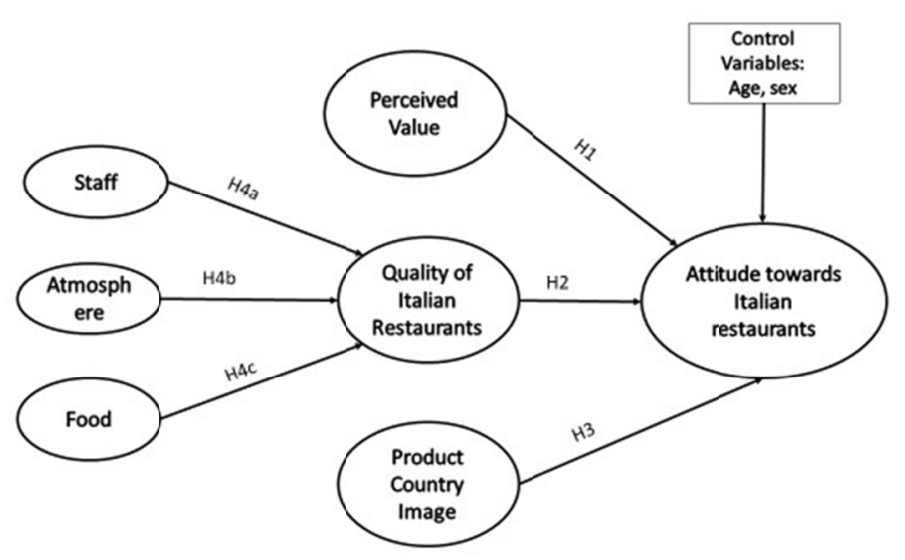

Figure 1. Theoretical model

\section{Methodology}

The previous theoretical hypotheses have been empirically investigated through a structural equation modelling methodology (SEM) applied on the data collected through a survey conducted among actual customers of Italian restaurants in Denmark. Data were gathered in some of the most popular and renowned Italian Restaurants in the city centre of Copenhagen in December 2017. Before starting the data collection, the restaurant's owners were contacted to acquire their willingness to participate in the research study, in order for the interviewer to freely enter the restaurants during lunch or dinner time and approach their customers to ask them to participate in the survey. The major part of owners' restaurants gave a positive feedback. In this way, the data collection process avoided possible biases eventually due to concentrating the survey within the customers of a sole restaurant. A survey plan was then prepared based on a non-probability sampling method (Jayakrishnan et al., 2016) allowing data collection in both the lunch and the dinner services. Customers were invited to fulfill a questionnaire while sitting at the attending room at the restaurant's hall or at their table when they were waiting for ordering their dishes. Respondents were invited to evaluate their previous experiences of eating in an Italian restaurant, assessing not only their perceptions concerned with the quality of the dining offer experienced and its affordability in terms of value for money, but also the overall image possessed by the Italian cuisine in their mind.

Denmark was selected for the empirical analysis of the study due to the different cuisine traditions featuring Denmark and Italy: the former Nordic and more linked with the Viking heritage; the latter Mediterranean. This is entailing a different usage of raw food materials in preparing dishes in restaurants and different tastes. At the same time, Danish people are very fond of Italian lifestyle, culture and goods: the Danes themselves like to refer to their country as the 'Italy of the North' and Italy remains a favourite holiday destination amongst Danish tourists (Palmitesta, 2016). Denmark is also increasingly well known for its Michelin-starred restaurants and high-end gastronomy scene, so it was considered as an adequate framework for the study aims.

In total, a number of 216 questionnaires were collected. 12 questionnaires were then excluded as not fully completed. At the end of the day, 204 completed and valid questionnaires were processed. Gender is equally represented in the dataset: males $(49 \%)$ and females $(51 \%)$. The age clusters are distributed as follows: $23 \%$ are younger than 25 years old, $46.1 \%$ are aged between 25 and 35 years old, $20.6 \%$ are $36-50$ years old; $8.3 \%$ are 51-65 years, while only $2.0 \%$ are older than 65 years. In terms of household income, $27.5 \%$ of the interviewees earn less than $36.000 € /$ year; $36.4 \%$ of them earn $36-70.000 € /$ year; $20.1 \%$ respondents earn more than $100.000 € /$ year and $16.2 \%$ of them earn $70-100.000 € /$ year. The family household size of respondents is as follows: $22.5 \%$ of respondents are single; $36.3 \%$ of the interviewees living as a couple; $15.7 \%$ of respondents live in a three-people family; $19.1 \%$ of respondents have a family household size of four members and $6.4 \%$ of respondents have a family household size of five or more members.

\subsection{Measures}

The questionnaire, previously pre-tested on a small group of Danish customers of Italian restaurants, is structured on two sections: the first section evaluates the seven psychometric constructs of the theoretical model 
proposed, while the second section considers the demographic characteristics of the sample. The 19 items composing the empirical model (Table 1) were derived from the literature on consumer behavior, service quality and Country-of-Origin and measured on 7-point Likert scales $(1=$ strongly disagree and $7=$ strongly agree $)$, apart from attitude and perceived quality that were assessed on a semantic differential scale.

Attitude towards Italian restaurants was measured by the means of three items derived from Phillips, Asperin \& Wolfe (2013). Perceived Quality of Italian restaurants is an overall evaluation based on an extended scale taken from that used by Cronin and Taylor (1992), while Perceived Value was measured using three items adapted from the paper of Ryu, Lee \& Gon Kim (2012). Three items of the original scale of Roth and Romeo (1992) measure the country image construct consisting in the Perception of the Italian Cuisine (PCI). The previous studies conducted by Amin et al. (2013) and Mohsin and Lockyer (2010) were used to assess the three most important components of service quality in full-service restaurants, that are as follows: two items compose the Staff construct, two items define the Atmosphere construct, and three items measure the Food construct.

Table 1. Measures and standardized factor loadings

\begin{tabular}{|c|c|c|c|c|c|}
\hline Original scale & Constructs & Items & & F.L. & T-value \\
\hline \multirow{4}{*}{$\begin{array}{l}\text { adapted from Phillips } \\
\text { et al. (2013) }\end{array}$} & Attitude & \multicolumn{4}{|l|}{ Could you please rate your attitude towards Italian food } \\
\hline & towards Italian & Very Negative/ Very positive & ATT1 & 0.712 & n.d. \\
\hline & Restaurants & Very Bad/ Very Good & ATT2 & 0.780 & 9.319 \\
\hline & $(\mathrm{ATT})$ & Very Unsound/ Very Sound & ATT3 & 0.894 & 9.069 \\
\hline \multirow{4}{*}{$\begin{array}{l}\text { Cronin \& Taylor, } \\
(1992)\end{array}$} & Perceived & \multicolumn{4}{|c|}{ Could you please rate the overall level of quality of Italian food in your perception? } \\
\hline & Quality & Very low-quality/ Very high-quality & PQ1 & 0.904 & n.d. \\
\hline & Italian & Very bad/Very good & PQ2 & 0.815 & 18.167 \\
\hline & $\begin{array}{l}\text { Restaurants } \\
\text { (PQ) }\end{array}$ & Inferior/ Outstanding & PQ3 & 0.893 & 21.065 \\
\hline \multirow{3}{*}{$\begin{array}{l}\text { adapted from Ryu et } \\
\text { al. (2012) }\end{array}$} & \multirow{3}{*}{$\begin{array}{l}\text { Perceived } \\
\text { Value }(\mathrm{PV})\end{array}$} & Italian food restaurants offer good value for money & PV1 & 0.776 & n.d. \\
\hline & & $\begin{array}{l}\text { The dining experience in Italian food restaurants } \\
\text { provided me great value as compared to others }\end{array}$ & PV2 & 0.831 & 9.548 \\
\hline & & $\begin{array}{l}\text { The dining experience in Italian food restaurants was } \\
\text { worth the money }\end{array}$ & PV3 & 0.703 & 9.772 \\
\hline adapted from & \multirow{4}{*}{$\begin{array}{l}\text { Product } \\
\text { Country Image } \\
(\mathrm{PCI})\end{array}$} & \multicolumn{4}{|c|}{$\begin{array}{l}\text { Could you please rate the extent to which, in your opinion, each of the following attributes } \\
\text { characterizes the Italian cuisine? }\end{array}$} \\
\hline Roth \& & & Innovative & PCI1 & 0.614 & n.d. \\
\hline (1992) & & High status & $\mathrm{PCI} 2$ & 0.728 & 7.451 \\
\hline \multirow{3}{*}{$\begin{array}{l}\text { adapted from Amin et } \\
\text { al. (2013); Mohsin \& } \\
\text { Lockyer (2010) }\end{array}$} & & Excellent presentation of dishes & PCI3 & 0.786 & 8.091 \\
\hline & \multirow{2}{*}{$\begin{array}{l}\text { Staff } \\
(\text { STAFF })\end{array}$} & Friendly restaurant managers/staff & STAFF1 & 0.930 & n.d. \\
\hline & & Staff's willingness to help & STAFF2 & 0.873 & 13.039 \\
\hline \multirow{5}{*}{$\begin{array}{l}\text { adapted from Amin et } \\
\text { al. (2013); Mohsin \& } \\
\text { Lockyer (2010) } \\
\text { adapted from Amin et } \\
\text { al. (2013); Mohsin \& } \\
\text { Lockyer (2010) }\end{array}$} & \multirow{2}{*}{$\begin{array}{l}\text { Atmosphere } \\
\text { (ATM) }\end{array}$} & Cleanliness of the restaurant/utensils & ATM1 & 0.793 & n.d \\
\hline & & Tidiness of the restaurant & ATM2 & 0.890 & 7.414 \\
\hline & \multirow{3}{*}{$\begin{array}{l}\text { Food } \\
(\text { FOOD) }\end{array}$} & Food quality & FOOD1 & 0.770 & n.d. \\
\hline & & Food portions & FOOD2 & 0.810 & 12.123 \\
\hline & & Food tastiness & FOOD3 & 0.780 & 9.959 \\
\hline
\end{tabular}

\subsection{Confirmatory Factor Analysis}

The validity of the posited hypotheses was assessed using two steps as suggested by Anderson and Gerbing (1988). First, by the means of the confirmatory factor analysis (CFA) the unidimensionality and convergent validity of the employed measures were tested. Second, a covariance-based structural equation model with the Maximum Likelihood method (CB-SEM) was used to measure paths between constructs. The two procedures were performed using the software Lisrel 8.80 (Jöreskog \& Sörbom, 2006).

The CFA confirmed the convergence and discriminant validity of the measurement model. Indeed, as reported in Table 1, all items exhibited significant (t-values $>7$ ) and substantial (factor loading $\geq 0.614$ ) values (Hu \& Bentler, 1999). Moreover, all the items composing the measurement model showed a high item-total correlation, proving their ability to measure the expected latent constructs. 


\subsubsection{Validity of the Measurement Model}

The convergent validity was confirmed by the good values reached by both the Average Variance Extracted (AVE) and the Composite Reliability (CR) higher than their threshold values [AVE $>0.5$ (Fornell \& Larcker, 1981), CR >0.7 (Steenkamp \& van Trijp, 1991)]. Further, the Fornell and Larcker criterion (1981), verifying that each construct shares more variance with its own measures than it shares with other constructs (bold values in Table 2), confirmed the discriminant validity of the investigated measures.

Table 2. Convergent and discriminant validity and correlation matrix

\begin{tabular}{lccccccccc}
\hline Constructs & AVE & CR & & & & & & \\
\hline Attitude & 0.507 & 0.840 & $\mathbf{0 . 7 1 2}$ & & & & & \\
Perceived Quality & 0.760 & 0.904 & 0.572 & $\mathbf{0 . 8 7 2}$ & & & & & \\
Perceived Value & 0.596 & 0.815 & 0.334 & 0.218 & $\mathbf{0 . 7 7 2}$ & & & \\
Staff & 0.814 & 0.897 & 0.301 & 0.339 & 0.497 & $\mathbf{0 . 9 0 2}$ & & \\
Atmosphere & 0.710 & 0.830 & 0.298 & 0.314 & 0.403 & 0.609 & $\mathbf{0 . 8 4 3}$ & \\
Food & 0.619 & 0.830 & 0.347 & 0.376 & 0.514 & 0.658 & 0.774 & $\mathbf{0 . 7 8 7}$ \\
Product Country Image & 0.508 & 0.754 & 0.261 & 0.175 & 0.227 & 0.366 & 0.442 & 0.425 & $\mathbf{0 . 7 1 3}$ \\
\hline
\end{tabular}

The analysis of the CB-SEM fit indicators proves a virtuous overall fit. The Satorra and Bentler chi-square results to be significant $\left(\chi_{(\mathrm{SB})}^{2}(162)=225.591, \mathrm{p}<0.00\right)$ evidencing the possible presence of multicollinearity in the dataset that is refuted by both the not-significant value of the Close-Fit RMSEA ( $p$-value $=0.762)$ and the $\chi^{2} / \mathrm{df}$ ratio (1.389) lower than 2. The Standardized Root Mean Square Residual value (SRMR=0.077) evidences no specific problem with residuals. In general, all the fit indexes show good values such as, for example, the Goodness of Fit Index value $(\mathrm{GFI}=0.892)$ or some of the incremental fit measurements like the Normed-Fit-Index $(\mathrm{NFI}=0.950)$ or the Comparative Fit Index $(\mathrm{CFI}=0.985)$, that exhibit values higher than 0.90 .

\section{Results}

The structural equation model presented in Figure 2 shows good predictive abilities for both Perceived Quality and Attitude towards Italian restaurants.

First, the three antecedents determining service quality perceptions of Italian restaurants by customers are able to explain $15.6 \%$ of the variance related to the overall perceived quality of Italian restaurants. Specifically, the restaurant's staff and the food offer exert a positive and significant effect on perceived quality of Italian restaurants, confirming $\mathrm{H} 4 \mathrm{a}(\mathrm{H} 4 \mathrm{a}: \beta=0.158, \mathrm{p}<0.05)$ and $\mathrm{H} 4 \mathrm{c}(\mathrm{H} 4: \beta=0.259, \mathrm{p}<0.05)$. Indeed, a helpful and friendly staff and a rich menu based on qualitative and tasty food have a positive impact on consumers' perception of the overall quality of the service offered by Italian restaurants. Instead, a not significant result was found concerning the effect that the restaurant atmosphere has on overall consumers' perception of Italian restaurant quality; as a consequence, $\mathrm{H} 4 \mathrm{~b}$ resulted as not supported.

Second, all the paths modelled in the structural model are able to explain $41.7 \%$ of the variance of attitude towards Italian restaurants, being $\mathrm{R}_{\mathrm{ATT}}{ }^{2}=0.417$. In detail, the main driver of attitude towards Italian restaurants is perceived quality, confirming our second hypothesis $(\mathrm{H} 2: \beta=0.508, \mathrm{p}<0.01)$. The higher the customer perceives the Italian restaurant as being of high quality, the higher his/her positive attitude towards it. Positive and significant is also the effect exerted by Perceived Value concerning the offer proposed by Italian restaurants on attitude towards them, confirming the first hypothesis proposed in the theoretical model conceptualized (H1: $\beta=0.217, p<0.01)$. When the dining experience in Italian food restaurants is perceived as worth the money, consumer attitude positively improves. Results also confirm our third hypothesis: the effect exerted by product country image on attitude towards Italian restaurants is positive and significant $(\mathrm{H} 3: \beta=0.123, \mathrm{p}<0.01)$. Indeed, a high status food with an excellent presentation of dishes are characteristics of the Italian cuisine able to improve consumers attitude towards Italian restaurants in the Nordic country under investigation.

To verify possible demographic characteristics able to deeply explain Danish attitude towards Italian restaurants, the gender and the age variables were included in the structural model as control variables. As shown in Figure 2, no significant effect was found concerning customers sex: consequently, Danish men and women show similar attitude towards Italian restaurants. Conversely, as proved by the significant and negative effect exerted by age of respondents on their attitude towards Italian restaurants, we can argue that in Denmark, the higher the age of the consumer, the lower his/her attitude to eat Italian restaurant. 


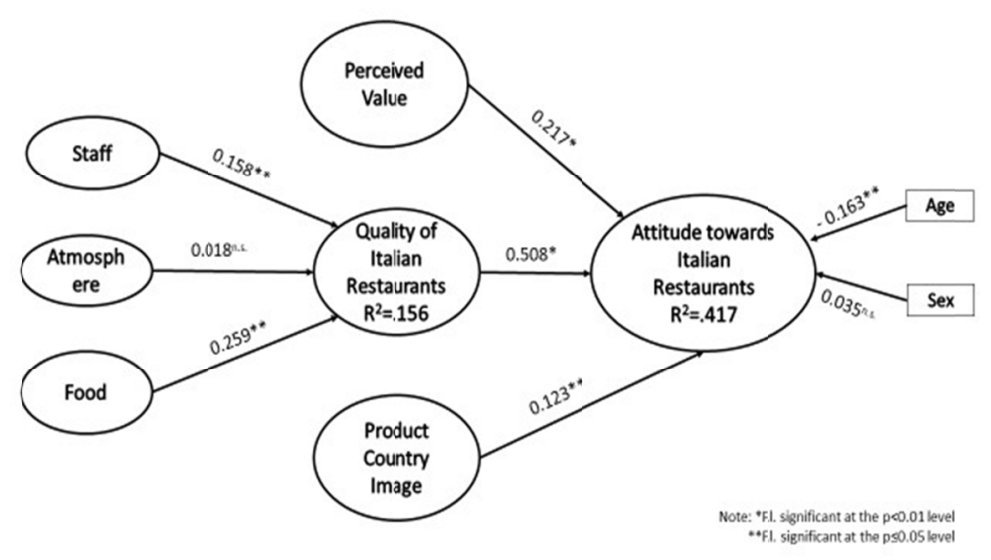

Figure 2. Structural model results

\subsection{Mediation Analysis}

As confirmed by the results of the Sobel test, one of the most parsimonious mediation test in SEM methodology, the restaurant's menu has a positive and significant indirect effect on attitude towards Italian restaurants, as follows: MENU $\rightarrow$ PQ $\rightarrow$ ATT: $\beta=0.155, p<0.05$. Albeit with a less significant effect, also the restaurant's staff indirectly contributes towards the increase of customers attitude towards Italian restaurants (STAFF $\rightarrow$ PQ $\rightarrow$ ATT: $\beta=0.067, p<0.10$ ). The indirect effect of restaurants' atmosphere on attitude resulted to be not significant.

\section{Discussion, Limitations and Further Studies}

The paper contributes to the literature on consumer behavior and international marketing investigating the effect of product country image in the full-service restaurant sector and in a multi-cue perspective, that is: showing the role played by both service quality and value attributes as well as the product country image construct. Indeed, the structural equation model results show that customers' evaluation of an ethnic restaurant is influenced by different factors. First, service quality attributes are key, as they are influencing the overall perception of the service offer proposed by Italian restaurants, stimulating a positive attitude towards this national cuisine. Indeed, in the eating choice, the quality of the restaurant offer represents a primary element. Second, the value of the service as perceived by customers is highly considered in the choice of a dining offer. Restaurant offers considered too expensive or too cheap can dramatically influence consumers attitude towards the ethnic cuisine. Both results are in line with the main service literature findings.

A relevant contribution of this paper concerns the product country image construct: the link between the country and the dining offer emerges to be highly relevant. When the product country image of a country, like Italy, renowned all over the world for its good food, is positive, consumers are more willing to display a positive attitude towards it. Nevertheless, the perception of the Italian cuisine resulted to be weaker in influencing Danish attitude towards Italian restaurants than the previous antecedents. Accordingly, both managers of the Italian restaurants located abroad and institutions operating at a national level to support the widespread of the Italian cuisine all over the world should improve the image of the Italian food culture in the Nordic area, to achieve a better perception by Danish customers. Finally, this paper shows an overall better predisposition towards ethnic food by younger generations. On one hand, this aspect is relevant for the companies and managers operating in the dining sector, who can target their offer and communication strategy to specific clusters of customers. On the other hand, this finding opens the debate to the need to find new service formulas, able to bring adult customers closer to the consumption of ethnic food.

Although the paper contributes to the COO literature in several ways, some limitations are present and might be examined in further studies. First, the survey was performed in one of the Nordic countries, and caution should be exerted in generalize results. Indeed, in the COO literature it is well consolidated the statement that each country is characterized by specific peculiarities that can reduce the generalizability of results. In further studies, an alternative Nordic country should be used as setting for the empirical analysis, in order to check for possible similarities and differences between Nordic countries. Moreover, future studies should compare Nordic vs Mediterranean or Arabic, African and Asian countries, to understand how the measures identified in the theoretical model may act differently in changing countries/cultures. Further, the present study does not consider moderator variables typical of the $\mathrm{COO}$ literature (i.e. product knowledge/familiarity, ethnocentrism, fit); in 
future works, the literature investigating the ethnic cuisine should consider to include one or more of these variables to add a piece of knowledge to this stream of investigation. Finally, yet importantly, it has been taken for granted the interviewees' ability to answer not influenced by their personal mood. Indeed, psychometric surveys lack in control for the personal mood of respondents.

\section{Acknowledgments}

Even if authors contributed equally to the study, Elisa Martinelli dedicated greater consideration to the introduction, to the literature review and to the theoretical background and hypotheses (paragraphs 1, 2, 3), while Francesca De Canio wrote the methodology, tested the empirical model, commented the results and contributed in their discussion (paragraphs 4, 5 and 6).

\section{References}

Ahmed, S., \& D'Astous, A. (1995). Comparison of country of origin effects on household and organizational buyers' product perceptions. European Journal of Marketing, 29(3), 35-51. https://doi.org/10.1108/03090569510145741

Ahmed, Z. U., Johnson, J. P., Ling, C. P., Fang, T. W., \& Hui, A. K. (2002). Countryof- origin and brand effects on consumers' evaluations of cruise lines. International Marketing Review, 19(3), 279-302. https://doi.org/10.1108/02651330210430703

Aishah, N., Corresponding, N. Z., Zakaria, N., Zahari, M. S. M., Othman, Z., Noor, S. M., \& Kutut, M. Z. (2010) Thai food in Malaysia: Diagnosing restaurant operators' and patrons' acceptance levels. International Journal of Business and Management, 5(4), 142-149. https://doi.org/10.5539/ijbm.v5n4p142

Amin, M., Yahya, Z., Ismayatim, W. F. A., Nasharuddin, S. Z., \& Kassim, E. (2013). Service quality dimension and customer satisfaction: An empirical study in the Malaysian hotel industry. Services Marketing Quarterly, 34(2), 115-125. https://doi.org/10.1080/15332969.2013.770665

Anderson, J. C., \& Gerbing, D. W. (1988). Structural Equation Modeling in Practice: A Review and Recommended Two-Step Approach. Psychological Bulletin, 103(3), 411-23. https://doi.org/0033-2909/88/\$00.75

Berentzen, J. B., Backhaus, C., Michaelis, M., Blut, M., \& Ahlert, D. (2008). Does "made in..." also apply to services? An empirical assessment of the country-of-origin effect in service settings. Journal of Relationship Marketing, 7(4), 391- 405. https://doi.org/10.1080/15332660802508364

Bilkey, W. J., \& Nes, E. (1982). Country-of-origin effects on product evaluations. Journal of International Business Studies, 13(1), 89-100. https://doi.org/10.1057/palgrave.jibs.8490539

Choo, H., Chung, J. E., \& Pysarchik, D. (2004). Antecedents to new food product purchasing behavior among innovator groups in India. European Journal of Marketing, 38(5/6), 608-625. https://doi.org/10.1108/03090560410529240

Clemes, M. D., Gan, C., \& Sriwongrat, C. (2013). Consumers' choice factors of an upscale ethnic restaurant, Journal of Food Products Marketing. 19(5), 413-438. https://mpra.ub.uni-muenchen.de/88449/

Cronin, Jr. J. J., \& Taylor, S. A. (1992). Measuring service quality: a reexamination and extension. Journal of Marketing, 56(3), 55-68. https://doi.org/10.2307/1252296

Deloitte. (2017). La ristorazione $\quad$ italiana nel mondo. https://www2.deloitte.com/it/it/pages/consumer-business/articles/la-ristorazione-italiana-nel-mondo---deloit te-italy---consumer-b.html

Fischer, P. M., \& Zeugner-Roth, K. P. (2017). Disentangling country-of-origin effects: the interplay of product ethnicity, national identity, and consumer ethnocentrism. Marketing Letters, 28(2), 189-204. https://doi.org/10.1007/s11002-016-9400-7

Fishbein, M., \& Ajzen, I. (1975). Belief, Attitude, Intention, and Behavior. Reading, Mass.: Addison-Wesley.

Fisk, R. P., Brown, S. W., \& Bitner, M. J. (1993). Tracking the evolution of the services marketing literature. Journal of Retailing, 69(1), 61-103. https://doi.org/10.1016/S0022-4359(05)80004-1

Fornell, C., \& Larcker, D. F. (1981). Evaluating structural equation models with unobservable variables and measurement error. Journal of Marketing Research, 18(1), 39-50. https://psycnet.apa.org/doi/10.2307/3151312

Ha, J., \& Jang, S. S. (2010a). Perceived values, satisfaction, and behavioral intentions: The role of familiarity in 
Korean restaurants. International Journal of Hospitality Management, 29(1), 2-13. http://dx.doi.org/10.1016/j.ijhm.2009.03.009

Ha, J., \& Jang, S. (2010b). Effects of service quality and food quality: the moderating role of atmospherics in an ethnic restaurant segment. International Journal of Hospitality Management, 29(3), 520-529. https://doi.org/10.1016/j.ijhm.2009.12.005

Han, C. M. (1989). Country image: halo or summary construct? Journal of Marketing Research, 26(2), $222-229$. https://doi.org/10.1177\%2F002224378902600208

Han, H., \& Hyun, S. S. (2017). Impact of hotel-restaurant image and quality of physical-environment, service, and food on satisfaction and intention. International Journal of Hospitality Management, 63, 82-92. https://doi.org/10.1016/j.ijhm.2017

Han, H., \& Ryu, K. (2009). The roles of the physical environment, price perception, and customer satisfaction in determining customer loyalty in the family restaurant industry. Journal of Hospitality and Tourism Research. 33(4), 487-510. https://doi.org/10.1177/2F1096348009344212

Hjalager, A. M., \& Corigliano, M. A. (2000). Food for tourists - determinants of an image. International Journal of Tourism Research, 281-293. https://doi.org/10.1002/1522-1970(200007/08)2:4\%3C281::AID-JTR228\%3E3.0.CO;2-Y

Hu, L. T., \& Bentler, P. M. (1999). Cutoff criteria for fit indexes in covariance structure analysis: Conventional criteria versus new alternatives. Structural Equation Modeling: A Multidisciplinary Journal, 6(1), 1-55. https://doi.org/10.1080/10705519909540118

Im, S., Bhat, S., \& Lee, Y. (2015). Consumer perceptions of product creativity, coolness, value and attitude. Journal of Business Research, 68(1), 166-172. https://doi.org/10.1016/j.jbusres.2014.03.014

Javalgi, R., Cutler, B., \& Winans, W. (2001). At your service! Does country of origin research apply to services? Journal of Services Marketing, 15(7), 565-582. https://doi.org/10.1108/08876040110407491

Jayakrishnan, S., Chikhalkar, R., \& Chaudhuri, R. (2016). Understanding the Role of Consumer Factors and Store Factors in Private Label Purchase. International Journal of Business and Management, 11(7), 223-236. https://doi.org/10.5539/ijbm.v11n7p223

Jöreskog, K. G., \& Sörbom, D. (2006). LISREL 8.80 for Windows. Lincolnwood, IL: Scientific Software International.

Kim, J. H., \& Jang, S. (2016). Determinants of authentic experiences: An extended Gilmore and Pine model for ethnic restaurants. International Journal of Contemporary Hospitality Management, 28(10), 2247-2266. https://doi.org/10.1108/IJCHM-06-2015-0284

Lin, L. Y., \& Chen, C. S. (2006). The influence of the country-of-origin image, product knowledge and product involvement on consumer purchase decisions: an empirical study of insurance and catering services in Taiwan. Journal of consumer Marketing, 23(5), 248-265. https://doi.org/10.1108/07363760610681655

Martin, I. M., \& Eroglu, S. (1993). Measuring a multi-dimensional construct: country image. Journal of Business Research, 28(3), 191-210. https://psycnet.apa.org/doi/10.1016/0148-2963(93)90047-S

McDougall, G. H. G., \& Levesque, T. (2000). Customer satisfaction with services: Putting perceived value into the equation. Journal of Services Marketing, 14(5), 392-410. https://doi.org/10.1108/08876040010340937

Michaelis, M., Woisetschläger, D. M., Backhaus, C., \& Ahlert, D. (2008). The effects of country of origin and corporate reputation on initial trust: An experimental valuation of the perception of Polish consumers. International Marketing Review, 25(4), 404-422. https://doi.org/10.1108/02651330810887468

Mohsin, A., \& Lockyer, T. (2010). Customer perceptions of service quality in luxury hotels in New Delhi, India: an exploratory study. International Journal of Contemporary Hospitality Management, 22(2), 160-173. https://doi.org/10.1108/09596111011018160

Motsi, T., \& Park, J. E. (2019). National Stereotypes as Antecedents of Country-of-Origin Image: The Role of the Stereotype Content Model. Journal of International Consumer Marketing, 1-13. https://doi.org/10.1080/08961530.2019.1653241

Palmitesta, A. (2016). How a special relationship has developed with the Italy in the south. Retrieved from http://cphpost.dk/community/how-a-special-relationship-has-developed-with-the-italy-in-the-south.html 
Papadopoulos, N., \& Heslop, L. A. (2003). Country equity and product-country images: state-of-the-art in research and implications. InS. C. Jain (Ed.), Handbook of Research in International Marketing. Edward Elgar, Cheltenham, Northampton.

Parasuraman, A., Zeithaml, V. A., \& Berry, L. L. (1988). SERVQUAL: A Multiple-Item Scale for Measuring Consumer Perceptions of Service Quality. Journal of Retailing, 64, 12-40.

Pecotich, A., Pressley, M., \& Roth, D. (1996). The impact of country of origin in the retail service context. Journal of Retailing and Consumer Services, 3(4), 213-224. https://doi.org/10.1016/0969-6989(95)00080-1

Phillips, W. J., Asperin, A., \& Wolfe, K. (2013). Investigating the effect of country image and subjective knowledge on attitudes and behaviors: US Upper Midwesterners' intentions to consume Korean Food and visit Korea. International Journal of Hospitality Management, 32, 49-58. https://doi.org/10.1016/j.ijhm.2012.04.003

Roth, M. S., \& Romeo J. B. (1992). Matching product category and country image perceptions: A framework for managing country-of-origin effects. Journal of International Business Studies, 23(3), 477-497. https://doi.org/10.1057/palgrave.jibs.8490276

Ryu, K., Lee, H. R., \& Gon Kim, W. (2012). The influence of the quality of the physical environment, food, and service on restaurant image, customer perceived value, customer satisfaction, and behavioral intentions. International Journal of Contemporary Hospitality Management, 24(2), 200-223. https://doi.org/10.1108/09596111211206141

Samiee, S. (2010). Advancing the country image construct-a commentary essay. Journal of Business Research, 63(4), 442-445. http://dx.doi.org/10.1016/j.jbusres.2008.12.012

Schooler, R. D. (1965). Product bias in Central American common market. Journal of Marketing Research, 2(4), 394-397. https://doi.org/10.2307/3149486

Steenkamp, J. B., \& Van Trijp, H. (1991). The use of lisrel in validating marketing constructs. International Journal of Research in Marketing, 8(4), 283-299. https://doi.org/10.1016/0167-8116(91)90027-5

Sulek, J. M., \& Hensley, R. L. (2004). The relative importance of food, atmosphere, and fairness of wait: The case of a full-service restaurant. Cornell Hotel and Restaurant Administration Quarterly, 45(3), 235-247. http://dx.doi.org/10.1177/0010880404265345

Susskind, A. M., \& Chan, E. K. (2000). How Restaurant Features Affect Check Aberages: A Study of the Toronto Retaurant Market. Cornell Hotel and Restaurant Administration Quarterly, 41(6), 56-63. https://doi.org/10.1016/S0010-8804(00)80023-3

Swait, J., \& Sweeney, J. C. (2000). Perceived value and its impact on choice behaviour in a retail setting. Journal of Retailing and Consumer Services, 7(2), 77-88. http://dx.doi.org/10.1016/S0969-6989(99)00012-0

Tsai, C. T. S., \& Lu, P. H. (2012). Authentic dining experiences in ethnic theme restaurants. International Journal of Hospitality Management, 31(1), 304-306. http://dx.doi.org/10.1016/j.ijhm.2011.04.010

Usunier, J. C. (2006). Relevance in business research: the case of country-of-origin research in marketing. European Management Review, 3, 60-73. https://doi.org/10.1057/palgrave.emr.1500049

Verlegh, P. W., \& Steenkamp, J. B. E. (1999). A review and meta-analysis of country-of-origin research. Journal of Economic Psychology, 20(5), 521-546. https://doi.org/10.1016/S0167-4870(99)00023-9

Zeithaml, V., Parasuraman, A., \& Berry, L. (1985). Problems and strategies in services marketing. Journal of Marketing, 48(2), 33-48. https://doi.org/10.1177/002224298504900203.

Zeithaml, V. A. (1988). Consumer perceptions of price, quality and value: A means-end model and synthesis of evidence. Journal of Marketing, 52, 2-22. https://doi.org/10.2307/1251446

Zeugner-Roth, K. P., Žabkar, V., \& Diamantopoulos, A. (2015). Consumer ethnocentrism, national identity, and consumer cosmopolitanism as drivers of consumer behavior: A social identity theory perspective. Journal of International Marketing, 23(2), 25-54. https://doi.org/10.1509/jim.14.0038

Zeugner-Roth, K., \& Diamantopoulos, A. (2009). Advancing the country image construct. Journal of Business Research, 62(7), 726-740. https://doi.org/10.1016/j.jbusres.2008.05.014 


\section{Copyrights}

Copyright for this article is retained by the author(s), with first publication rights granted to the journal.

This is an open-access article distributed under the terms and conditions of the Creative Commons Attribution license (http://creativecommons.org/licenses/by/4.0/). 